\title{
The Effect of Multimedia Technology On Undergraduates' Learning Burnout in College English
}

\author{
Zhang Min \\ School of Foreign Languages, \\ China West Normal University \\ Nanchong, China \\ zhangmin62280@163.com
}

\author{
Wen Tingting \\ School of Marxism \\ China West Normal University \\ Nanchong, China \\ 39706265@qq.com
}

\begin{abstract}
This paper did an experiment among some undergraduates to testify the effect of multimedia technology on college English learning burnout. It is found that multimedia technology can enhance learners' interest in English learning, and help reduce the level of learning burnout, but the results partly rely on how the teacher use this technology.
\end{abstract}

Keywords-college English; learning burnout; undergraduates; multimedia technology; effect

\section{INTRODUCTION}

With the rapid development of our country’s economy, China's international status has become higher and higher. And cross-cultural communications are more and more popular. Many foreigners come to China to travel or set up their careers, and more and more Chinese students pursue their study overseas. During these courses English plays an important role. To undergraduates they are the center stone of our society, and their qualities have an important effect on our nation. So it's really necessary for them to have a good command of English to keep pace with the world. However, in college English learning process, some of them often show ignorance of English: being late for English classes, refusing to hand in homework, being mind-absent in English classes and so on. These phenomenons reveal that learning burnout has existed among them. So it's necessary to investigate into the reasons and degrees of their learning burnout. Some researchers found that educational technology can arouse learning interest and improve understanding of learning contents and efficiency. This paper did a research to testify the effect of multimedia technology on learning burnout in college English.

\section{DEFINITION AND CHARACTERISTICS OF LEARNING BURNOUT}

\section{A. Definition}

The concept of learning burnout rooted from job burnout. In 1974 the famous American clinical psychologist Herbert Freudenberger originated the concept of burnout. At the beginning it was used in people-serving industry. Later on it developed to a wider field. The definition of learning burnout usually tracked back to job burnout. Learning burnout is a phenomenon that students became exhausted for long-term academic pressure, lack of enthusiasm for studies and activities, estrange themselves from classmates and have a negative attitude to course work [1]. Though different people may have different definitions from various views, the core is the same, that is, learning burnout has 3 dimensions: emotional exhaustion (feelings of being emotionally overextended and exhausted with one's work), depersonalization (the development of negative uncaring attitudes to others) and negative personal accomplishment (the loss of feelings of self-competence and dissatisfaction with one's achievements)[2].

\section{B. Charicteristics}

- According to Meier, learning burnout exhibits some characteristics, which adversely affect educational performances: 1) an inability to learn which can't be explained by intellectual, sensory, or health factors; 2) an inability to build or maintain satisfactory interpersonal relationship with peers and teachers; 3 ) inappropriate types of behavior or feelings under normal circumstances; 4) a general pervasive mood of unhappiness or depression; 5) a tendency to develop physical symptoms or fears associated with personal or school problems. [1]

With learning burnout students may not want to go to the classes, even in the classroom, they are mind-absent, silent, or disturb others. In this case, not only their studies will degrade, but also the whole class's study atmosphere will be influenced. So it's significant to investigate into the reasons that result in this phenomenon. In fact, many researchers abroad have done many researches about it. Ditsa kafry and Ayala Pines pointed that learning burnout may embody the internal features which include pressures inherent in the individual's roles and imposed on the cognitive capacity, the need for meaningfulness and achievement, and external features which include pressures imposed on the individual by the physical organizational and social environment [3]. And some recent researches found that learning burnout is not only influenced by the social and individual factors, but also by the instructional contents, teaching methods, etc [4].

\section{RESEARCH DESIGN}

Nowadays multimedia technology is widely used in education. In many universities, multimedia classrooms are springing up. Due to its convenience, teachers always prefer it. In order to testify the effect of multimedia technology on 
undergraduates' college English learning burnout, an experiment was carried out.

\section{A. Research objects}

The research objects come from two normal universities in Sichuan Province. In each university 8 classes are chosen out at random. All the participants are freshmen. In the stage of preparation, they are required to fill in a questionnaire about learning burnout in 15minutes. And then the statistics are analyzed with the help of SPSS 11.0. According to the results, in each university four classes are finally picked out to participate in this research, whose differences are not significant in the total score of learning burnout $(\mathrm{p}>0.05)$. And then, they are divided into two groups: control group and experimental group. In experimental group, only multimedia technology is applied in English classes (computer, internet, slides, etc), while in control group, multimedia technology cannot be used. After 3 semesters, the students are required to finish the same questionnaire that they filled in at the beginning of the first semester. Later on the statistics are analyzed by SPSS11.0 to see if there exist any differences in the degree of their learning burnout.

Totally there are 414 college students. In experimental group there are 212 students, and in control group there are 202 students.

\section{B. Research instrument}

In this research a questionnaire, named "A Questionnaire on Undergraduates' Learning Burnout in College English” is carried out. This instrument is formed on the basis of other two learning burnout questionnaires respectively by Kenyan and YangLi-xian [5] [6]. Their questionnaires are widely applied by many researchers at home, and have a good reputation for its high reliability. After some necessary modification, this questionnaire came out. In this questionnaire there are 34 questions, which can be divided into 3 dimensions: dejection, improper behavior and reduced personal accomplishment. In dimension of dejection there are 14 items, in dimension of improper behavior there are 11 items and in dimension of reduced personal accomplishment there are 9 items. The questionnaire adopts 5-point Likert scale. The higher the score is, the more serious learning burnout is. After the researchers' explanation on some terms, the participants are required to finish the questionnaire in 20 minutes by themselves. And then the results are analyzed with the help of SPSS 11.0.

\section{RESULTS AND ANALYSIS}

\section{A. Contrast between control group and experimental group}

According to table 1 it's clear that control group got a higher score in total score and every dimension of learning burnout than experimental group. It demonstrates that students in control group are in a more serious state of learning burnout in college English learning. Their dejection is more severe, and their behaviors are more improper, and their personal accomplishments are much more reduced.
TABLE I. THE AVERAGE SCORE OF ALL VARIBLES

\begin{tabular}{|c|l|l|l|l|}
\hline & & Mean & $\begin{array}{c}\text { Std. } \\
\text { Deviation }\end{array}$ & $\begin{array}{c}\text { Std.Error } \\
\text { Mean }\end{array}$ \\
\hline \multirow{2}{*}{$\begin{array}{c}\text { Learning } \\
\text { burnout }\end{array}$} & CG & 81.7079 & 16.66255 & 1.17237 \\
\cline { 2 - 5 } dejection & EG & 74.9434 & 19.64728 & 1.34938 \\
\hline & EG & 34.3267 & 5.09675 & 0.35861 \\
\hline \multirow{2}{*}{$\begin{array}{c}\text { Improper } \\
\text { behavior }\end{array}$} & CG & 22.4953 & 5.88359 & 0.40409 \\
\cline { 2 - 5 } & EG & 20.9057 & 9.21337 & 0.63278 \\
\hline $\begin{array}{c}\text { Reduced personal } \\
\text { accomplishment }\end{array}$ & CG & 25.0941 & 6.10489 & 0.42954 \\
\cline { 2 - 5 } & EG & 22.5425 & 6.90306 & 0.47410 \\
\hline
\end{tabular}

Table 2 exhibits whether these differences are significant or not. As is shown here, these differences are all significant $(p<0.05)$. What's more, in terms of the total score of learning burnout, dejection and improper behavior, the differences are very significant $(\mathrm{p}<0.01)$. It reveals that multimedia technology has a positive effect on students' college English learning. With the help of multimedia technology students have a much more positive attitude to college English study, and their self-esteem is much higher and they're more interested in college English study. From these analyses it's obvious that multimedia technology is effective in enhancing learners' English learning. In other words, it can help reduce undergraduates' learning burnout in college English learning.

TABLE II. INDEPENTDENT SAMPLE TEST

\begin{tabular}{|c|c|c|c|c|c|}
\hline & t & df & $\begin{array}{c}\text { Sig(2- } \\
\text { tailed) }\end{array}$ & MD & Std. ED \\
\hline $\begin{array}{c}\text { Learning } \\
\text { burnout }\end{array}$ & -3.769 & 412 & 0.000 & -6.76452 & 1.79462 \\
\hline dejection & -3.289 & 412 & 0.001 & -2.83145 & 0.86082 \\
\hline $\begin{array}{c}\text { Improper } \\
\text { behavior }\end{array}$ & -3.977 & 412 & 0.000 & -2.55161 & 0.63975 \\
\hline RPA & -2.548 & 412 & 0.011 & -1.38147 & 0.54213 \\
\hline
\end{tabular}

MD refers to mean Difference, Std. ED refers to Std Error Difference, RPA refers to reduced person

$$
\text { al accomplishment }
$$

\section{B. Contrast between the former and the latter in experimental group}

A contrast was carried out in experimental group to testify the differences of students' performances in the two questionnaires. The means are shown here.

TABLE III. THE AVERAGE SCORE OF EXPERIMENTAL GROUP

\begin{tabular}{|c|l|l|l|l|}
\hline & dejection & $\begin{array}{c}\text { Improper } \\
\text { behavior }\end{array}$ & RPA & $\begin{array}{c}\text { Learning } \\
\text { burnout }\end{array}$ \\
\hline The first time & 30.8726 & 20.6792 & 22.1673 & 73.7191 \\
\hline The second time & 31.4953 & 20.9057 & 22.5425 & 74.9434 \\
\hline
\end{tabular}

It's clear that in the second questionnaire participants get higher scores in every dimension and the total learning burnout than that in the first one. It means that undergraduates' college English learning burnout become more serious after 3 semesters. Though they are better than participants in control group, it's not a satisfying tendency.

\section{DISCUSSION}

The results show that multimedia technology has a positive effect on undergraduates’ college English learning. 
It can degrade the level of learning burnout, and enhance learners' interest in English. This is also proved by a later meeting with some participants from both groups.

After the questionnaire a face-to-face discussion was carried out. Some participants came from control group, others came from experimental group. In this meeting some students from control group complain that college English course is out-of-date. Without PPT or visual-audio materials, the class is cheerless; and the teaching methods are so traditional: the teacher explains the text, new words and phrases, and then students make drills. So it's dull and boring which makes them lose interest in English study; while students from experimental group maintain that in English classes they can not only learn new words, phrases, but also with the help of English movies, pictures, and slides, they had a deeper understanding about English culture, and they can contact the pure oral English, which make them more interested in English study. What's more, thanks to computers and internet, they can contact teachers at once about their difficulties. Since it's virtual, they don't feel nervous or shy, so that they can ask any questions that puzzle them, and they get the answer at once. They regard it as a useful way to learn English well. Therefore, it's not surprised to hear many say that they make a big progress in English. They are more satisfied than students from control group.

In the second questionnaire, undergraduates from experimental group get a better result than that of control group. However, according to their scores in both questionnaires, it's clear that both groups get a higher score in the second time. In other words not only participants in control group but also undergraduates from experimental group are under a more serious state of learning burnout in college English learning after 3-semeter English learning. Why? In the discussion with some participants, many a student from experimental group points out that some English teachers don't have a good command of multimedia technology. Sometimes in English classes they spend much time working on how to operate the computer; and others complain that PPT is so simple, not vivid. Due to these demerits, English classes can't appeal to them fully. Of course there are some other causes resulting in this phenomenon. But it's obvious that English teachers must learn more knowledge about multimedia technology so that they can qualify as a good teacher, and get a better teaching result. In addition, some teachers apply multimedia technology in every English course no matter whether it is suitable or not. So some students also complain teachers are just like an operator of computers, and there is little eye-toeye communication with teachers in the class, which makes them depressed and discouraged. So teachers should be clear how and when exploit software in class and they must know computer is not an "all or nothing" matter [7].

\section{CONCLUSION}

1. Multimedia technology can help reduce undergraduates' college English learning burnout.

2. To reach better results English teachers should learn more knowledge about multimedia technology.

3. English teachers should always work on teaching methods.

\section{ACKNOWLEDGMENT}

The authors got found from China West Normal University (number: 12A011).

\section{REFERENCES}

[1] Meier S F \& Schmeck R. The burned-out college student: a descriptive profile. Journal of College Student Personal, vol 40, Januarary 1985, pp. 63-69

[2] Byrne, B. M. Burnout: investigaiting the impacy of background variables for elementary, intermediate, secondary, and university educators. Teaching and Teacher Education, vol 7, February, 1991, pp.197-209.

[3] Pines A. \& Kafry, D. The experiment of tedium in life and work. Human Relations, vol 33, July 1980, pp. 477-503.

[4] Liat, Kulik. Burnout, perceived stress, and resources among educated, working Jews and Moslem Arabs in Israel: A cross-cultural perspective. Journal of Cross-cultural Psychology, vol. 40, May 2009, pp. 894-900

[5] KenYan. Research on conditions of undergraduats' learning bounout and the influence factor. D. Shangai: Shanghai Normal University, may, 2008.(in Chinese)

[6] YangLi-xian. Research on conditions of current college students' learning burnout and its relationships with speciality commitment. D. Fujian: Fujian Normal University, April, 2004. (in Chinese)

[7] Crookal \& Martin. 1985. Citec in Kenning, MM and MJ Kenning(1990). Computers and Language Learning: current theory and practice. New York: E. Harwood. 